TIP Periodica Polytechnica

Transportation Engineering

42(1), pp. 53-61, 2014

DOI: $10.3311 /$ PPtr.7282

http://www.pp.bme.hu/tr/article/view/7282

Creative Commons Attribution (i)

RESEARCH ARTICLE

\section{Determination of vehicle density of inputs and outputs and model validation for the analysis of network traffic processes}

Tamás Péter / Sándor Fazekas

RECEIVED 21 October 2013; Accepted 8 January 2014

\section{Abstract}

This article studies the processes in large-scaled road traffic networks. The described system applies a new dynamical model considering the real circumstances. The validation of the model is performed with cross-section traffic data and velocity measurement of GPS-equipped cars participating in the traffic. The model was set up during the modeling process of the city of Györ.

\section{Keywords}

class of positive systems · large nonlinear dynamic network model $\cdot$ modeling of transport processes $\cdot$ validation $\cdot$ road transport processes analysis

\section{Tamás Péter}

Department of Control for Transportation and Vehicle Systems, Budapest University of Technology and Economics,

Stoczek u. 2., H-1111 Budapest, Hungary

e-mail: peter.tamas@mail.bme.hu

\section{Sándor Fazekas}

Department of Control for Transportation and Vehicle Systems,

Budapest University of Technology and Economics,

Stoczek u. 2., H-1111 Budapest, Hungary

e-mail: alexanderfazekas@gmail.com

\section{Introduction}

The theory in question applies to systems belonging to the class of positive systems.

To this class belong, for example, fluids moving dynamically between reservoirs in a network, where Euler's law of conservation of mass holds, and the basic structure is the interconnected network itself, Bastin, G. (1999). These models are used to describe the multitude in different systems, for example, in traffic systems, that manage the flow of cars on the road, or the flow of aircrafts in the airspace in that the control is performed with groups of computers Fu, Y. et al, (2006).

In the case of macroscopic models the traffic is treated as a flow of a medium applying the so-called liquid or gas flow approach. Macroscopic models were studied to describe the traffic flow using the analogy between the traffic and fluid flows as the starting point in Lighthill, M.J. and Whitham, G.B. (1955), Ashton, W.D. (1966), Bécsi, T. and Péter, T. (2008).

In the area of macroscopic modeling of traffic processes the concept of the class of positive systems came up naturally.

The first definition of positive systems was given in Luenberger, D. (1979): A positive system is a system in which the state variables are non-negative. In the majority of the analyzed traffic processes the original physical meaning of the states meet this requirement. The classic literature on traffic processes sets up in the most cases general linear system of equations, without using the positive qualities of the process. We might think that the properties recognized in the general linear systems are also true for positive systems without any restrictions; however, this is not the case as described in Varga, I. (2007). The controllability and observability conditions of positive systems cannot be clearly derived with methods known from general systems. This problem is particularly true if a non-negative co-domain is required not only for the states, but for the actuator signal, as well. Therefore, the description of the traffic processes as purely positive systems is not a trivial task from the control theory point of view. The control task in this case means that we need to control the system from a state to another state so that the states take non-negative values during the state 
transitions, as well. In this subject matter the description of the systems and controllability was given in the systematizing works of Caccetta, L. and Rumchev, V.G. (2000) and Farina, L. and Rinaldi, S. (2000), and Bacciotti, A. (1983), Coxson, P.G. and Shapiro, H. (1987) and Valcher, M.E. (1996). In the publications of Boothby, W.M. (1982) and Sachkov, Y.L. (1997) the following theorem regarding real matrix $\boldsymbol{A}$ applied in control theory can be declared: The system is positive if and only if the matrix $\boldsymbol{A}$ is a Metzler matrix, i.e. the elements outside the main diagonal are non-negative (the elements in the main diagonal may be arbitrary).

We developed a software based on our non-linear traffic model. This software called PannonTraffic is object-oriented, easily developable, modularly structured, and it contains the features for creating road network, simulating it and conducting an analysis. Stróbl, A., Péter, T. (2013).

The elements of the road infrastructure (lanes, traffic lights, pedestrian crossings, bicycle roads, etc.) are mapped through an interactive surface input while they are parameterized by several features. We succeeded to implement the simulation with a high-performance algorithm. S. Fazekas, T. Peter: (2012), Fazekas Sándor, Péter Tamás (2012.1), Fazekas, S., Péter T. ( 2013)

\section{Traffic model for analysis}

A very important new structural result from the modeling point of view is that the dynamic model of the road network is made up of the multitude of the same elements and the codomain of each $x_{i}$ state parameter value is located in the interval of $[0,1]$. Therefore, the parking lots may also be treated as generalized sections of the model and are dynamic components of the network as the lanes, Péter, T. and Bokor, J. (2010, 2011),

Another important new structural result is that, regardless of the map-graph, a unified hyper-matrix structure can be specified for the mathematical modeling of large-scale road network processes, which for a network located not necessarily in a singly connected domain describes the entire system of relations between network elements (internal-internal, external-internal, internal-external and external-external relations).

The new description of the dynamic model of the system is the base for the calculation and control of the system processes.

In the referred contributions there is discussion about a constructed network, which is bounded by a closed curve. Péter, T. (2012.1), Péter, T., Szabó, K. (2012) and Péter Tamás (2012.2). It contains $\mathrm{n}$ sectors of internal network and $\mathrm{m}$ sectors from external network. We assume that the external sectors have directly connection to internal sectors and their state is known by measurements. The differential equation system is the following:

$$
\dot{x}=\langle L\rangle^{-1}\left[K_{\underline{\underline{11}}}(x, s) x+K_{12}(x, s) s\right]
$$

where $x \in \mathfrak{R}^{\mathrm{n}}, \forall \mathrm{x}_{\mathrm{i}} \in[0,1],(\mathrm{i}=1,2, \ldots, \mathrm{n}), \dot{x} \in \mathfrak{R}^{\mathrm{n}}, \mathrm{s} \in \mathfrak{R}^{\mathrm{m}}, \forall$ $\mathrm{s}_{\mathrm{i}} \in[0,1],(\mathrm{i}=1,2, \ldots, \mathrm{m}), L=\operatorname{diag}\left\{1_{1}, \ldots, 1_{\mathrm{n}}\right\}, 1_{\mathrm{i}}$ length of road sections in the main diagonal $\left(\forall 1_{i}>0, i=1,2, \ldots, n\right), K_{11} \in \mathfrak{R}^{\text {nxn }}$, $\mathrm{K}_{12} \in \mathfrak{R}^{\mathrm{nxm}}$.

The operation of the network is determined by $\mathrm{K}_{11}$ and $\mathrm{K}_{12}$ relational matrices. These matrices assign the existence of the relationship between every sector of the system, and at the same time it represents the differential equation system describing the dynamic operation of the sections, so thus the constricted network.

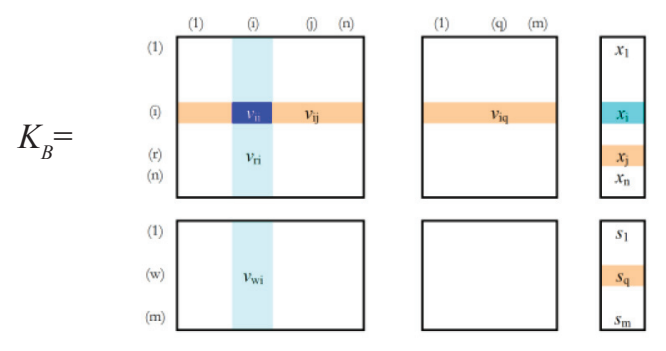

Fig. 1. The relational matrices of the $i$-th inner sector

The determination of the vehicle density in the i-th inner sector, according to the (1) continuous model:

$$
\begin{aligned}
\dot{x}_{i}(t) & =\frac{1}{l_{i}}\left[\left[\sum_{j=1 ;(j \neq i)}^{n} v_{i j} \cdot x_{j}(t)+\sum_{q=1}^{m} v_{i q} \cdot s_{q}(t)\right.\right. \\
& \left.\left.-\left(\sum_{r=1 ;(r \neq i)}^{n} v_{r i}+\sum_{w=1}^{m} v_{w i}\right) x_{i}(t)\right]\right]
\end{aligned}
$$

where

$$
\begin{aligned}
v_{i j}= & S\left(x_{i}(t)\right) \cdot V\left(x_{i}(t), x_{j}(t), \underline{e}_{i}, \underline{e}_{j}\right) \cdot E\left(x_{j}(t)\right) \\
\cdot & \alpha_{i j}(x(t), t) \cdot \beta_{i j}(x(t), t) \cdot \gamma_{i j}(x(t), t) \cdot u_{i j}(t) \\
v_{i q}= & S\left(x_{i}(t)\right) \cdot V\left(x_{i}(t), s_{q}(t), \underline{e}_{i}, \underline{e}_{q}\right) \cdot E\left(s_{q}(t)\right) \\
& \cdot \alpha_{i q}(x(t), t) \cdot \beta_{i q}(x(t), t) \cdot \gamma_{i q}(x(t), t) \cdot u_{i q}(t) \\
v_{r i}= & S\left(x_{r}(t)\right) \cdot V\left(x_{r}(t), x_{i}(t), \underline{e}_{r}, \underline{e}_{i}\right) \cdot E\left(x_{i}(t)\right) \\
& \cdot \alpha_{r i}(x(t), t) \cdot \beta_{r i}(x(t), t) \cdot \gamma_{r i}(x(t), t) \cdot u_{r i}(t) \\
v_{w i}= & S\left(s_{w}(t)\right) \cdot V\left(s_{w}(t), x_{i}(t), \underline{e}_{w}, \underline{e}_{i}\right) \cdot E\left(x_{i}(t)\right) \\
& \cdot \alpha_{w i}(x(t), t) \cdot \beta_{w i}(x(t), t) \cdot \gamma_{w i}(x(t), t) \cdot u_{w i}(t)
\end{aligned}
$$

in case of fulfillment of the following relationship:

$$
\begin{aligned}
& \sum_{r=1 ;(r \neq i)}^{n} \alpha_{r i}+\sum_{w=1}^{m} \alpha_{w i}=1 \\
& v_{i i}=-\left[\left(\sum_{r=1 ;(r \neq i)}^{n} v_{r i}+\sum_{w=1}^{m} v_{w i}\right)\right]
\end{aligned}
$$




\subsection{Summary of the characteristics applied in the large road network model}

- In our model $0 \leq \mathrm{x}_{\mathrm{i}}(\mathrm{t}) \leq 1 ;(\mathrm{i}=1, \ldots, \mathrm{n})$ normalized vehicle density is used as state parameter. The total length of the vehicles in one stage or section is divided by the length of the stage or section. This calculation can also be used in the case of parking lots, so the parking lots are generalized sections of the model, as well.

- The object of the model is a positive non-linear system. In the network the medium flows with variable speed and according to the defined time-dependent distribution factors are denoted by $\alpha_{\mathrm{ij}}(\mathrm{t})$. The medium is represented by road vehicles. The speed depends on the vehicle density, the maximum value of which is limited in all sections. In addition, the speed function is influenced by weather and visibility conditions, road geometry, quality and width.

- $\beta_{\mathrm{ij}}(\mathrm{t})$ denotes the obstruction $\left(0 \leq \beta_{\mathrm{ij}}(\mathrm{t})<1\right)$ or facilitation $\left(1<\beta_{\mathrm{ij}}(\mathrm{t})\right)$ occurring at the transition between certain sections.

- $0 \leq \mathrm{u}_{\mathrm{ij}}(\mathrm{t}) \leq 1$ switching function operation takes into account the effect of traffic lights operating at the section transitions.

- Vehicles are exchanged between the parallel running sections (lanes), as well as between parking lots and sections in the network. This transfer is taken into account by the proportionality function $0 \leq \gamma_{\mathrm{ij}}(\mathrm{t})$ or $0 \leq \gamma_{\mathrm{ij}}\left(\mathrm{x}_{\mathrm{i}}(\mathrm{t}), \mathrm{x}_{\mathrm{j}}(\mathrm{t}), \mathrm{t}\right)$.

- Internal prohibiting automatisms operate on the network, as well: vehicles cannot be transferred from $\mathrm{j}$ to $\mathrm{i}$, if $\mathrm{i}$ is full, $\mathrm{x}_{\mathrm{i}}(\mathrm{t})=1 \Rightarrow \mathrm{S}\left(\mathrm{x}_{\mathrm{i}}(\mathrm{t})\right)=0$. Vehicles also cannot be transferred from $j$ to $i$, if $j$ is empty $x_{j}(t)=0 \Rightarrow$ $\mathrm{E}\left(\mathrm{x}_{\mathrm{j}}(\mathrm{t})\right)=0$. These conditions are easy to follow applying the normalized state parameters, which provide that in the model vehicles cannot be taken from empty sections (the density does not enter into the negative range), and also cannot be transferred to sections where the density has already reached 1.

- The network is analyzed on a not necessarily singly connected domain bounded by a closed curve "G". In the external sections, which are in direct transfer relation with a network section, the normalized traffic density $0 \leq \mathrm{s}_{\mathrm{i}}(\mathrm{t}) \leq 1 ;(\mathrm{i}=1, \ldots, \mathrm{m})$ is measured.

- The traffic model is the so-called macroscopic model.

- The mathematical model is a non-linear, non-autonomous differential equation system.

\section{Traffic modelling in the city of Györ}

Györ is the most important city of northwest Hungary situated on one of the most important Trans-European priority axis regarding to motorway, railway and waterway also. Its population is nationwide high, 131000 in 2011 and forcefully growing. Györ is Hungary's leader city in introducing new intelligent transportation technologies; in aspect of developing new technologies (electric car, intelligent communication of vehicles etc.) as well as applying them (integrated intelligent public transport system).

The city represents a wide variety of settlement structure. The historical downtown, the old and new residential areas are fastened to the industrial zones. In the last years some surrounding village was attached to the city enhancing the diversity of the city. This results in daily challenges for the transportation network to conduct the appearing traffic on the streets.

In a project supported by the European Union we investigated the traffic network of Györ.

Tamas Peter, Jozsef Bokor and Andras Strobl (2013) and Zsuzsanna Bede, Tamás Péter and Ferenc Szauter (2013).

One of the aims of this project is to prepare the network model of the whole city, estimate the needed parameters, and work out a control for being possible to manage the transportation processes optimally.

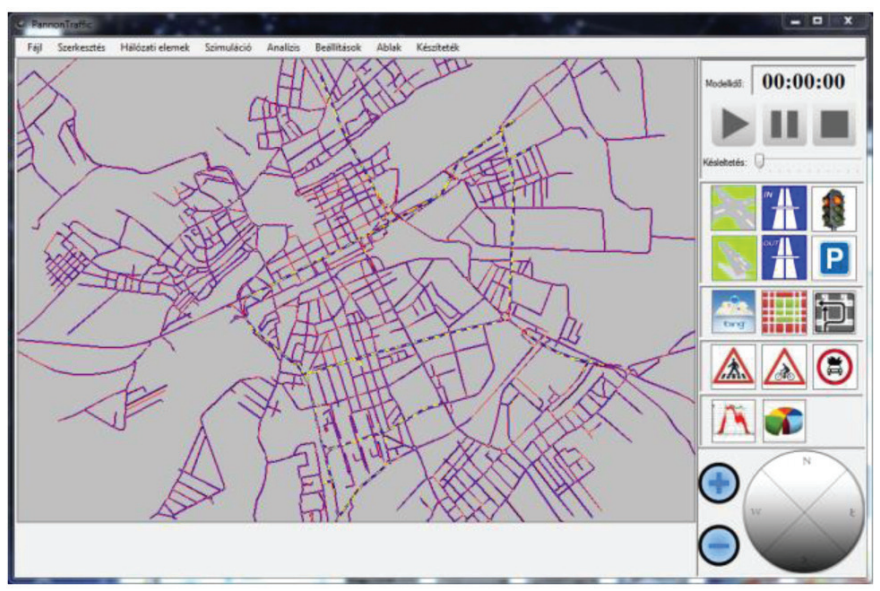

Fig. 2. Modelled network of Győr in our software

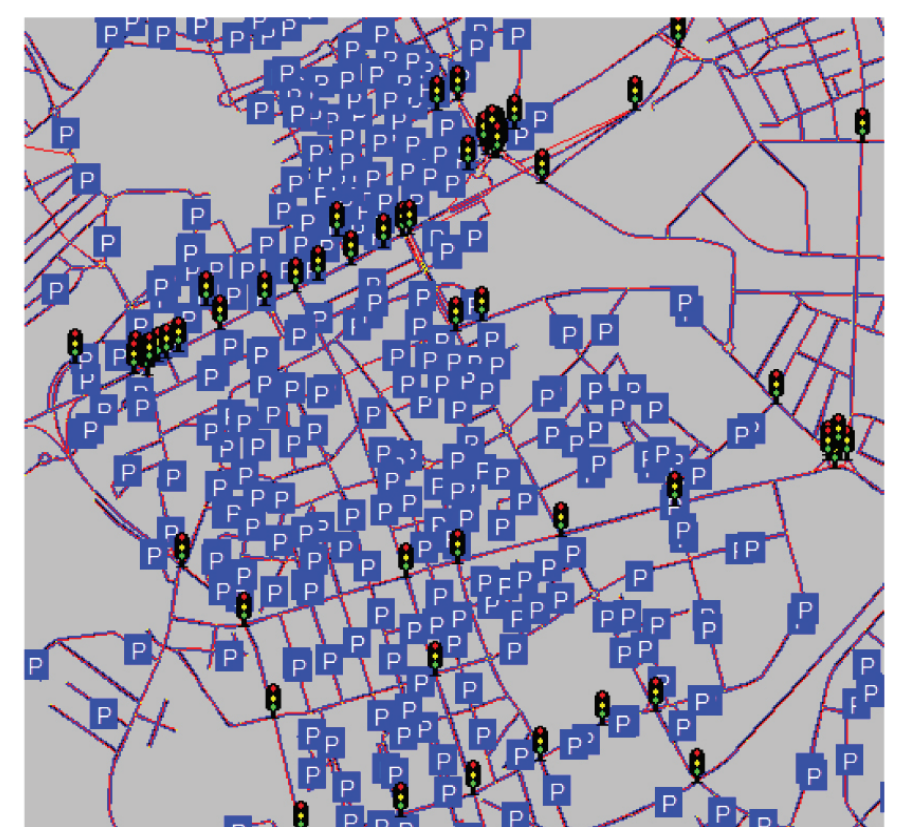

Fig. 3. Parking places and traffic lights in the example model 
Our software based on the mathematical model mentioned above is capable to cope with this large network, and to provide simulation results very quickly for further investigations and network developments.

Creating this $175 \mathrm{~km}^{2}$ sized network is executed in only a few minutes, which would be impossible without our development of about a month. This network consists of 4600 road sections (this is only the skeleton network) approximately $500 \mathrm{~km}$ of total length. This basic network has to be expanded by several lanes, bicycle roads (about $36 \mathrm{~km}$ ) and parking places.

We recently accomplished the surveying of parking places in public areas. Altogether we estimated parking places for 20 000 vehicles on approximately 650 spots. This number doesn't include the private parking places inside the residential parcels but includes the hidden parking places in the inner courts of the city centre's buildings. The latter was determined by opensource satellite images.

The spreading of roundabouts was due to low maintenance cost and since it can ensure continuous traffic flow (replacing the intersections regulated by traffic lights), Györ was the first city in Hungary where traffic light regulated roundabout was constructed and put in operation. Further speciality of this intersection type is the architecture; it was the first Hungarian turbo roundabout. Considering this and the several other roundabouts, respectively the tunnel and bridges of the city we can say the modelling of Györ is a very complex challenge.

As mentioned above Győr is situated next to a railway serving very high traffic. This excellent railway connection requires in addition some level crossings, that has to be modelled properly, as well. In our software there is a separate module for managing the railway-motorway crossings.

Other expansive task of modeling this city is the issue of traffic lights. With the decreasing number of traffic light regulated intersections there are more, than 60 intersections where traffic light is applied. Most of these traffic lights are supervised and in case of need the technical personel can do some kind of intervention from a central control room. In normal circumstances the intersections are controlled by some pre-defined programs. We had to record these programs in the model too, and define the phase groups related to this. Some factors in the model e.g. distribution, parking place occupation, parallel lane changes, etc. still have to be measured and validated to represent the reality.

\section{Calculation of boundary vehicle densities}

Let's suppose, on a boundary-section - which can be an input or an output section -, cross section traffic was measured.

We denote the quantity of measured standard vehicle throughput in 1 hour with $\mathrm{N}$, and the expected vehicle density on the range-section referring to this time interval with $\mathrm{s}$. The expected vehicle velocity is v. If the traversed standard vehicle quantity is given for shorter time intervals, the dynamics of the process can be enhanced.
The velocity $\mathrm{v}[\mathrm{m} / \mathrm{sec}]$ is a binary function in the dynamic model, since it's value depends on the sections before and after the analyzed cross section: $v=v(s, x), 4^{\text {th }}$ figure.

Initially there is no information on the $\mathrm{x}$ internal vehicle density, this value will be calculated by the dynamic model, therefore we will apply the $\mathrm{x} \approx \mathrm{s}$ approximation, accordingly $\mathrm{v}$ depends only on s. Essentially we handle the two sections as one having a common $s$ vehicle density.

In Fig. 4. it can be seen that cross section traffic is measured on the inputs of cross-hatched domain enclosed by the curve $\mathrm{G}$ (on bottom left), outer-inner merge is executed. Furthermore, cross section traffic is measured on the outputs of cross-hatched domain enclosed by the curve $\mathrm{G}$ (on top right), inner-outer merge is executed.

The $N$ [Passenger Car Equivalent (PCE)/hour] cross section vehicle traffic data related to the next 1 hour are given within 15 minutes time-blocks. Therefore the number of passed over Passenger Car Equivalent, denoted with $n$, can be calculated:

$$
n=\frac{N}{3600}[\mathrm{PCE} / \mathrm{sec}]
$$

Denote with $\mathrm{h}[\mathrm{m}]$ the length of the Passenger Car Equivalent.

Regarding to the base relationship applied to solve dynamic equations $(1,2,3,4,5)$ the $\Delta l[\mathrm{~m}]$ vehicle length, which is passed over in $\Delta t$ time is calculable:

$$
S \cdot E \cdot \alpha \cdot \beta \cdot s \cdot v \cdot u \cdot \Delta t=\Delta l
$$

In case of free flow: $S=1, E=1, u=1$. As no distribution is performed in the current case, therefore $\alpha=1$. We supposed no obstruction and facilitation, therefore $\beta=1$. The adjustment of $\beta$ will be implemented during the validation of the model. Furthermore, the throughput refers to a unit of time, therefore $\Delta t=1 \mathrm{sec}$. Following that the equation (7) results in the length $l[\mathrm{~m}]$ of traversed vehicles in $1 \mathrm{sec}$ :

$$
s \cdot v=l
$$

\section{However:}

$$
n=\frac{l}{h}
$$

also results in the number of traversed vehicles. Consequently 1 is known from the traffic measurement:

$$
l=n \cdot h
$$

Applying the $v=v(s)$ velocity-density function, based on (8) and (9) the s vehicle density is determinable.

The bibliography of velocity-density relationship offers several functions, e.g.: the Greenshields (1935) (linear), the Greenberg (1959) (logarithmic) forms. Further functions are 


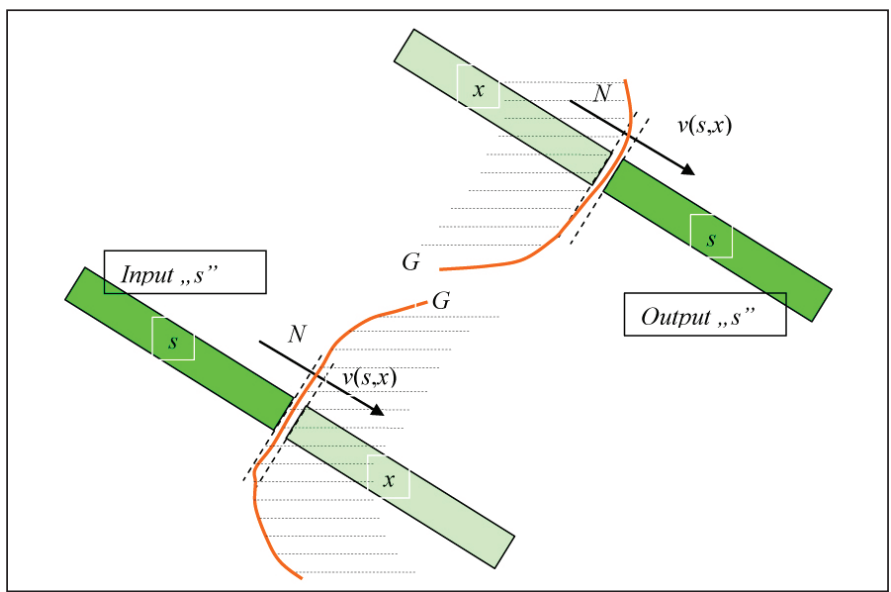

Fig. 4. The domain enclosed by the curve $\mathrm{G}$ and the relation of the input and output sections.

discussed by Kövesné Gilicze É. and Debreczeni G. (2003). These functions are stochastic relations based on measurements, wherein $V_{\operatorname{Max}}$ and other constants are derived from results of regression methods. The variable $\mathrm{x}$ denotes the vehicle density on a section, and $v(x)$ is the expected average speed of the vehicles processing on the section, depending on $\mathrm{x}$. The Fig. 5. shows different velocity-density functions.

The classical literature does not deal with the definition of the environmental vector, but the velocity is determined not only by vehicle density, but by other environmental parameterization, as well: this refinement can be implemented with the modification of $V_{\text {Max }}$, or via the modification of the function itself considering the weather, visibility, road quality, width of the road. These environmental, seasonal factors can be represented in the environmental parameter vector e in the relational matrix: $V=v(x, \underline{e})$.

$$
v(x, \underline{e})=\frac{e_{4} \cdot V_{\operatorname{Max}}}{e_{3}+e_{2} \cdot\left(\frac{x}{1-x^{e_{5}}}\right)^{e_{1}}}
$$

In this case, the parameter vector e contains 5 parameters:

$$
\underline{e}=\left[e_{1}, e_{2}, e_{3}, e_{4}, e_{5}\right]
$$

The following table demonstrates the favorable and unfavorable parameter domains. The internal domain is located between the two distinct domains, in most of the cases the practical parameter comes from this internal interval. The borders of the intervals are empirical values, in a given case the coordinates of the $\underline{e}=\left[e_{1}, e_{2}, e_{3}, e_{4}, e_{5}\right]$ parametervector are determined via regression analysis after the velocity - density measurement.

The specialty of the introduced $V=v(x, \underline{e})$ function is that it gives the same results as the linear function of Greenshields, if every parameters' value equals to 1 (Fig. 7.). This result shows that Greenshields' linear function has

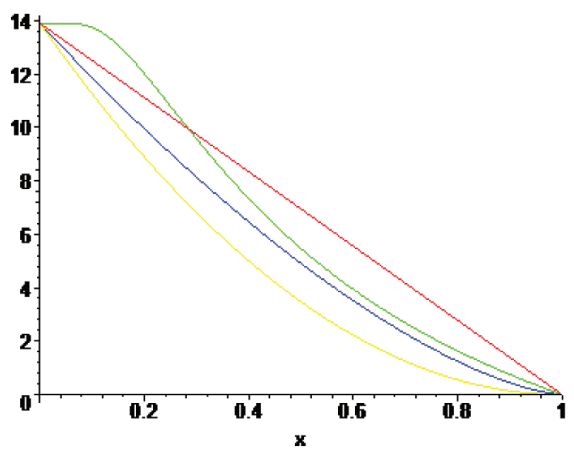

Fig. 5. $v(x)[\mathrm{m} / \mathrm{s}]$ vehicle velocity is the function of vehicle density

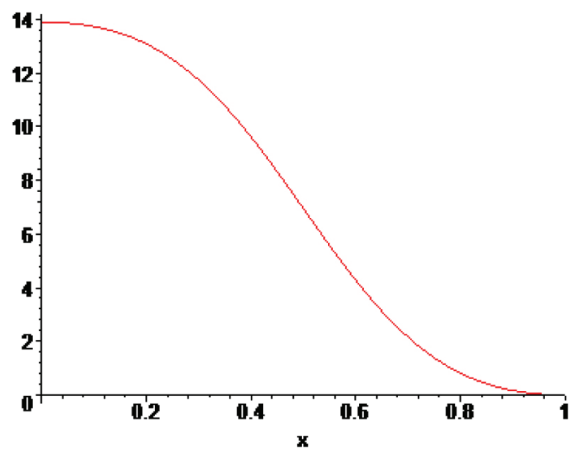

Fig. 6. $v(x)$ velocity - density function with $\mathrm{e}_{1}=2 ; \mathrm{e}_{2}=1 ; \mathrm{e}_{3}=1 ; \mathrm{e}_{4}=1 ; \mathrm{e}_{5}=1$ parameters.

\begin{tabular}{|c|c|c|c|}
\hline$e_{i}$ & $\begin{array}{l}\text { Meaning of the } \\
\text { parameter }\end{array}$ & Unfavorable cases & Favorable cases \\
\hline$e_{1}$ & Road quality & $\begin{array}{c}\text { Bad: } \\
\mathrm{e}_{1}=0.1-0.3\end{array}$ & $\begin{array}{c}\text { Good: } \\
e_{1}=3-4\end{array}$ \\
\hline$e_{2}$ & Curly road & $\begin{array}{l}\text { Lot of curves: } \\
\qquad e_{2}=3-4\end{array}$ & $\begin{array}{l}\text { Few curves: } \\
e_{2}=0.1-0.2\end{array}$ \\
\hline$e_{3}$ & Slippery road & $\begin{array}{c}\text { Bad, slippery: } \\
e_{3}=1.2-4\end{array}$ & $\begin{array}{c}\text { No slippery: } \\
\qquad e_{3}<1\end{array}$ \\
\hline$e_{4}$ & Safety, visibility & $\begin{array}{c}\text { Bad conditions: } \\
e_{4}=0.5-0.7\end{array}$ & $\begin{array}{c}\text { Good conditions: } \\
\qquad e_{4}>1\end{array}$ \\
\hline$e_{5}$ & Width of road & $\begin{array}{c}\text { Narrow: } \\
\mathrm{e}_{5}=0.1-0.2\end{array}$ & $\begin{array}{c}\text { Wide: } \\
\mathrm{e}_{5}>4\end{array}$ \\
\hline
\end{tabular}

Tab. 1. demonstration of the e parameter vector

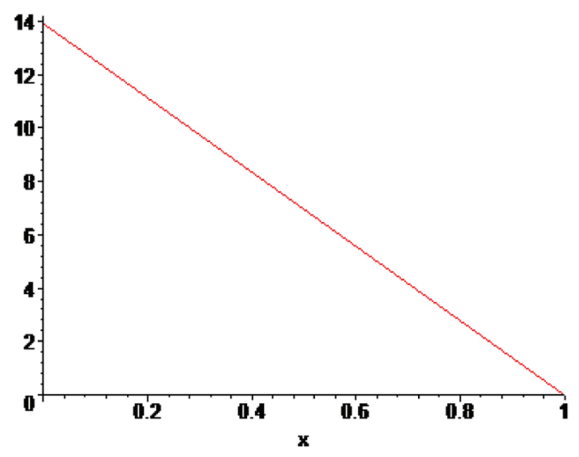

Fig. 7. $v(x)$ function, with $\mathrm{e}_{1}=1 ; \mathrm{e}_{2}=1 ; \mathrm{e}_{3}=1 ; \mathrm{e}_{4}=1 ; \mathrm{e}_{5}=1$ parameters. 
parameter values from the mid-range, so that provides really an average $\mathrm{v}(\mathrm{x})$ velocity-density function relationship in practice.

Therefore, many velocity functions exist. In the current case, the linear function will be used to solve (8):

$$
v(s)=V_{\text {Max }}(1-s)
$$

where $V_{\text {Max }}$ is the maximum allowed velocity:

$$
s \cdot V_{\text {Max }}(1-s)=l
$$

The vehicle density is expressed with the parameters $n, h$ and $V_{\text {Max }}$ :

$$
s_{1,2}=0.5 \pm \sqrt{0.25-\frac{n \cdot h}{V_{\operatorname{Max}}}}
$$

There are two possible vehicle density solutions, which satisfies the equation, unless:

$$
\frac{n \cdot h}{V_{\text {Max }}}=0.25
$$

The cross section traffic cannot be considered as state variable! Same amount of traffic can be transferred in case of the multiplication of small vehicle density and large velocity, or in case of the multiplication of large vehicle density and small velocity, see the Fig. 8.

To decide which the expected vehicle density variable is, the velocity of the traffic members at a given cross section should be determined. For this purpose, cross section traffic measurements should be supported with measurements via camera recorder, or the traffic counting method should be extended with velocity data measured via GPS equipped sampling cars.

\section{To summarize the following steps will be followed}

(1) To determine the expected value of the initial (input/output) vehicle density s, the connecting input section and output section will be merged. This joint section will be analyzed in the connection point, which is the place of the traffic counting. The expected vehicle density flowing through this point (cross section) is denoted by $\mathrm{s}$.

2 The data originated from the traffic counting will be transformed to $1 \mathrm{sec}(6)$.

(3) Supposing free flow, besides $S=1, E=1, u=1, \alpha=1, \beta=1$, $\Delta t=1$ the equation regarding to the transmitted vehicle length will be constructed, in such way the vehicle lengths regarding to $1 \mathrm{sec}$ will be determined.

(4) The velocity-density function will be selected, in this case it is the linear function (but it can be other function, if required)

5 The equation (11) will be solved with (12).

(6) Fig. 8. showed, that the cross section traffic measurement in a predefined time interval is not sufficient to determine the definite value of state variables of the traffic network sections (or the equivalent expected vehicle velocity values). Aside from the special case of maximal traffic, two different values are suitable as expected density state variable: s1 and s2. To decide between the two different values further measurement is required. For this purpose GPS equipped sampling cars are applied to traffic velocity measurements on the given sections.

$(7$ Afterwards, the above calculations will be executed on every input and output section, the expected vehicle density values will be adjusted. The simulation performed by the model calculates the vehicle densities and velocities of the given time interval on the internal network.

8 The validation will be performed with the optimal adjustment of $\alpha_{i j}, \beta_{i j}$ parameters. This process will be executed with the minimization of the difference between the measured and simulated internal traffic data, furthermore with the minimization of the difference between the measured and calculated velocity values.

\section{Györ - The traffic and simulation model of Szent István út and it's neighborhood}

\subsection{The review of the modeled network}

The model includes the street with one of the highest traffic in Győr, the Szent István Street (1. sz. föút) and its neighborhood. This traffic model plays an important role in the studies of environmental load, Stróbl András, Péter Tamás, Fazekas Sándor (2012), Stróbl, A., Péter, T. (2013).

From the traffic techniques point of view, the road includes two lanes for each directions; in case of classifier and line-up sections it is extended to three or four lanes. The traffic in the rush hours can exceed the $1000 \mathrm{PCE} /$ hour value in some interchanges. Traffic signals are installed in the interchanges of the high street.

\subsection{The construction of the network model}

Szent István Street constitutes the trunk of the network, related to this part, some connecting roads and intersections are also modeled. Fig. 9. shows the network model copied from the PannonTraffic software.

\subsection{Data and measurement}

The characteristics of the network

- 228 roads

- 9 interchanges controlled by traffic lights

- 38 other intersections

- 18 input sections

In case of model data, we used the cross-sectional measurement data executed in 2012. 63 cross sectional measurements are considered in the course of the analysis and validation. This information is extended with the traffic velocity measurement performed with GPS equipped cars. The velocity functions 


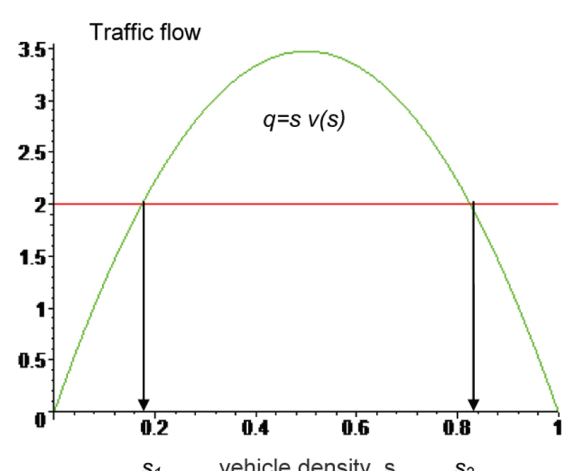

Fig. 8. The $s * v(s)$ traffic function and a constant value

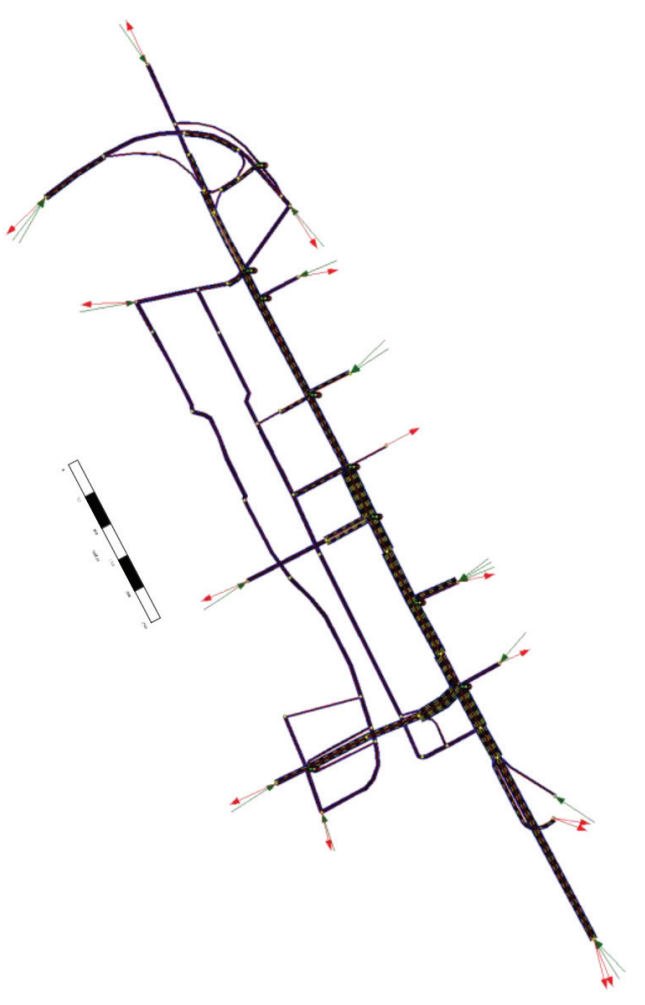

Fig. 9. Szent István Street represents the trunk of the network

related to the given time intervals are assigned to the proper sections. Fig. 10. shows such a measurement: the current example includes the measured velocity values on Szent István Street, beside entry and exit territory of the city.

We performed the traffic modeling with the PanonTraffic Engineer software.

\subsection{Phaseplans of traffic lights}

The phaseplans of the traffic controlling lights are provided by Magyar Közút Zrt. and the Self-government of the city of Györ (in some crossings there are more than 10 traffic directions defined, that means 12-15 relations elements in model level).

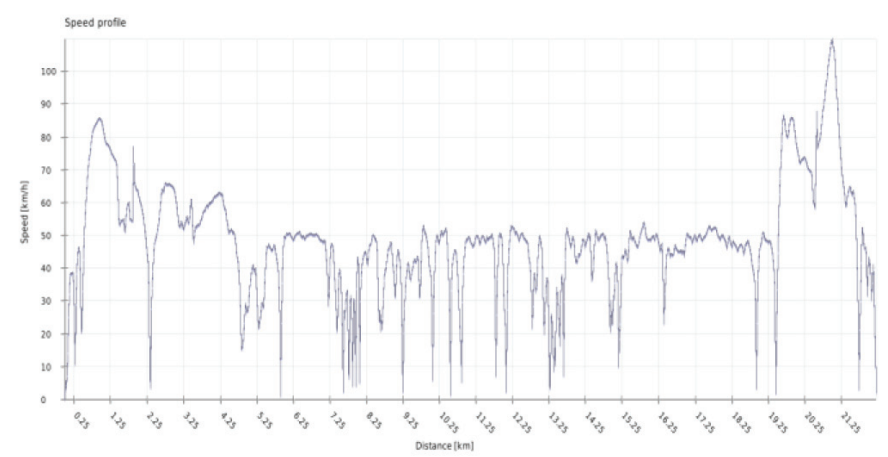

Fig. 10. The featuring velocity values depending on the sections

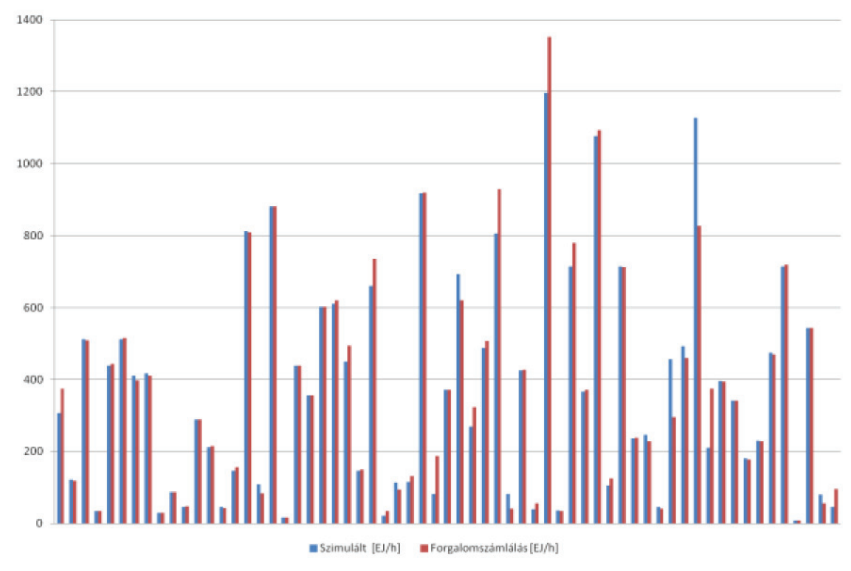

Fig. 11. The measured and simulated traffic correlate very well

\subsection{Preparation of network parameter validation}

To prepare the validation process, the modeling software was extended with validation functionality. The analysis showed that the measured and simulated cross-sectional traffic data correlates well, observing different network elements. After the evaluation, the correlation coefficient is:

$$
r_{x, y}=0.9925070033
$$

which can be regarded as $100 \%$ correlation practically.

We made some software improvements to export the average vehicle density calculated in course of the simulation in different timeframes.

Fig. 11. compares the simulated and measured traffic .

The simulation for the given interval $(7: 15$ - 8:15) was executed in 6 sec.

The simulation regarding to the 24 hour time interval was executed in 2 minutes 14 seconds. 


\section{Conclusions}

PannonTraffic software was used for modeling and simulation. The introduced model is an important sub-domain of the traffic network of Györ including Szent István Street. The validation of the model is carried out with the measured crosssectional traffic data and the result of GPS equipped cars performed velocity measurements.

The measured cross-sectional traffic data was split to quarterhour time intervals. The consideration of this time-frame created stable boundary conditions. The Lyapunov stability was observable for times in every hour in the investigated domain, and in any sub-domain. After the validation, the correlation coefficient between the measured and simulated cross-sectional traffic was $r_{x y}=0.9925070033$, which can be considered as $100 \%$ practically.

New scientific result: a dynamic traffic model was created based on the traffic data measured on boundaries and the velocity data measured in traffic. A validation method is elaborated for this model. The validation covered not only the traffic data of the boundaries but the measured traffic data of the inner crosssections, as well.

\section{Acknowledgements}

"Smarter Transport" - IT for co-operative transport system - The Project is supported by the Hungarian Government and co-financed by the European Social Fund. TÁMOP-4.2.2.C-11/1/KONV-2012-0012

\section{References}

1 Ashton W. D., The Theory of Road Traffic Flow. Methuen, London (1966).

2 Bacciotti A., On the positive orthant controllability of two-dimensional bilinear systems. Systems \& Control Letters, 3(1), 53-55 (1983). DOI: 10.1016/0167-6911(83)90038-5

3 Bastin G., Issues in modelling and control of mass-balance systems., in 'Stability and Stabilization of Nonlinear Systems' (ed.: Aeyels D., Lamnabhi-Laguarrigue F., van der Schaft A. J.,) Springer, London, 53-74 (1999).

Chapter DOI: $\underline{10.1007 / 1-84628-577-1 \_3}$

4 Boothby W. M., Some comments on positive orthant controllability of bilinear systems. SIAM Journal on Control and Optimization, 20(5), 634-644 (1982).

DOI: $10.1137 / 0320047$

5 Bécsi T., Péter T., Development and evalution of a Fuzzy-based Microscopic Vehicle-following model. Periodica Polytechnica Transportation Engineering, 36(1-2), 15-19 (2008). DOI: $10.3311 /$ pp.tr.2008-1-2.03

6 Caccetta L., Rumchev V. G., A survey of reachability and controllability for positive linear systems. Annals of Operations Research, 98(1-4), 101-122 (2000). DOI: $10.1023 / \mathrm{A}: 1019244121533$

7 Coxson P. G., Shapiro H., Positive input reachability and controllability of positive systems. Linear Algebra and its Applications, 94, 35-53 (1987). DOI: $10.1016 / 0024-3795(87) 90076-0$

8 Farina L., Rinaldi S., Positive linear systems: theory and applications. Wiley, New York (2000). DOI: $10.1002 / 9781118033029$

9 Fazekas S., Péter T., 3D traffic visualization. in 'First scientific workshop on transport, vehicles and logistics' Budapest University of Technology and Economics, Budapest 1-8 (2012).

10 Fazekas S., Péter T., Database system to support Győr's traffic modelization. 'Second Scientific workshop on transport, vehicles and logistics' Budapest University of Technology and Economics, Budapest 1-7 (2012.1)

11 Fazekas S., Péter T., Design of Györ's traffic database. 'Third Scientific Workshop on Transport, Vehicles and Logistics' Budapest University of Technology and Economics, Budapest 1-7 (2013).
12 Fu Y., Wang H., Lu C., Chandra R. S., Distributed utilization control for real-time clusters with load balancing. in 'Proceedings of the 27th IEEE International Real-Time Systems Symposium. Rio de Janeiro, Brazil', 137-146 (2006). DOI: $10.1109 /$ RTSS.2006.20

13 Greenberg H., An analysis of traffic flow. Operations Research, 7(1), 79-85 (1959). DOI: 10.1287 /opre.7.1.79

14 Greenshields B. D., A study of traffic capacity. in 'Proceedings of the Fourteenth Annual Meeting of the Highway Research Board held at Washington, D.C. December 6-7, 1934.', Highway Research Board Proceedings, 14, 448-477 (1935).

15 Kövesné Gilicze É., Debreczeni G., Intelligens közúti közlekedési rendszerek és út-jármü rendszerek matematikai modellezése és analizise. Kutatási jelentés BME Közlekedésüzemi Tanszék, Budapest, 1-49. (2003).

16 Lighthill M. J., Whitham G. B., On kinematic waves. I: Flood movement in long rivers, II: A theory of traffic flow on long crowed roads. Proceedings Royal Society, A229(4), 281-345 (1955).

I. DOI: $10.1098 /$ rspa.1955.0088

II. DOI: $\underline{10.1098 / \mathrm{rspa} .1955 .0089}$

17 Luenberger D. G., Introduction to dynamic systems. Wiley, New York (1979).

18 Péter T., Bokor J., Modeling road traffic networks for control. in 'Annual international conference on network technologies \& communications: NTC 2010, 29 - 30 November 2010. Phuket Beach, Thaiföld', 18-22 Paper 21. (2010).

19 Péter T., Bokor J., New road traffic networks models for control. GSTF International Journal on Computing, 1(2), 227-232 (2011). DOI: $10.5176 \quad 2010-2283 \quad 1.2 .65$

20 Péter T., Modeling nonlinear road traffic networks for junction control. International Journal of Applied Mathematics and Computer Science (AMCS), 22(3), 723-732 (2012.1). DOI: $10.2478 / \mathrm{v} 1006-012-0054-1$

21 Péter T., Szabó K., A new network model for the analysis of air traffic networks. Peridoica Polytechnica Transportation Engineering, 40(1), 39-44 (2012).

DOI: $10.3311 /$ pp.tr.2012-1.07 
22 Péter T., Paradigmaváltás, amely elvezetett a globális közúti hálózat müködésének leirásához és a dinamikus modell létrehozásához. in 'Innováció és fenntartható felszíni közlekedés konferencia (IFFK2012). Budapest, Magyarország, 2012.08.29-2012.08.31.', Paper 3, 3-19 (2012.2).

23 Péter T., Bokor J., Strobl A., Model for the analysis of traffic networks and traffic modelling of Gyorr. in " 1 st IFAC Workshop on Advances in Control and Automation Theory for Transportation Applications (ACATTA 2013), Istanbul, Turkey, 16-17 September 2013', 167-172 (2013).

DOI: $10.3182 / 20130916-2-T R-4042.00023$

24 Sachkov Y.L., On positive orthant controllability of bilinear systems in small codimensions. SIAM Journal on Control and Optimization, 35(1), 29-35 (1997). DOI: $10.1137 / \mathrm{S} 0363012994270898$

25 Stróbl A., Péter T., Fazekas S., Stratégiai zajtérkép készitése makroszkopikus közúti közlekedési modellt alkalmazó szoftverrel. in 'Innováció és fenntartható felszíni közlekedés konferencia (IFFK2012). Budapest, Magyarország, 2012.08.29-2012.08.31.', Paper 11, 71-75 (2012).
26 Stróbl A., Péter T., Traffic modeling of Győr in project Smarter Transport. in 'Third Scientific Workshop on Transport, Vehicles and Logistics' Budapest University of Technology and Economics, Budapest 1-7 (2013).

27 Bede Z., Péter T., Szauter F., Variable network model. in ' 1 st IFAC Workshop on Advances in Control and Automation Theory for Transportation Applications (ACATTA 2013), Istanbul, Turkey, 16-17 September 2013', 173-177 (2013). DOI: $\underline{10.3182 / 20130916-2-T R-4042.00026}$

28 Valcher M. E., Controllability and reachability criteria for discrete time positive systems. International Journal of Control, 65(3), 511536 (1996). DOI: $10.1080 / 00207179608921708$

29 Varga I., Közúti folyamatok paramétereinek modell alapú becslése és forgalomfüggö irányítása. PhD Értekezés Budapesti Müszaki és Gazdaságtudományi Egyetem, (2007). 